\title{
Pemanfaatan Akreditasi dalam Peningkatan Manajemen Madrasah di Kota Pekanbaru (Studi Kasus di Madrasah Tsanawiyah Swasta Kecamatan Tampan Kota Pekanbaru)
}

\author{
Sohiron \\ Universitas Islam Negeri Sultan Syarif Kasim Riau, Indonesia \\ sohiron@uin-suska.ac.id
}

\begin{abstract}
ABSTRAK
Akreditasi sekolah/madrasah adalah proses penilaian secara komprehensif terhadap kelayakan satuan atau program pendidikan, yang hasilnya diwujudkan dalam bentuk sertifikat pengakuan dan peringkat kelayakan yang dikeluarkan oleh suatu lembaga yang mandiri dan profesional. Manfaat akreditasi bagi madrasah adalah sebagai Acuan dalam upaya peningkatan mutu sekolah/madrasah dan rencana pengembangan sekolah/madrasah dan sebagai umpan balik dalam usaha pemberdayaan dan pengembangan kinerja warga sekolah/madrasah dalam rangka menerapkan visi, misi, tujuan, sasaran, strategi, dan program sekolah/madrasah. Penelitian ini dilaksanakan untuk mengetahui pemanfaatan akreditasi dalam peningkatan manajemen madrasah di Kota Pekanbaru (studi kasus di madrasah tsanawiyah swasta Kecamatan Tampan Kota Pekanbaru). Metode penelitian pengumpulan data dengan melakukan wawancara kepada 4 (empat) kepala madrasah tsanawiyah swasta di Kecamatan Tampan Kota Pekanbaru. Hasil penelitian bahwa madrasah telah memanfaatkan akreditasi peningkatan manajemen madrasah meliputi 5 aspek yaitu: 1). Aspek manajemen madrasah mengacu pada standar pengelolaan; 2). Aspek manajemen kurikulum mengacu pada standar isi, standar proses, standar kompetensi lulusan, standar penilaian pendidikan; 3). Aspek manajemen sumber daya manusia mengacu pada standar pendidik dan tenaga kependidikan; 4). Aspek manajemen sarana dan prasarana mengacu pada standar sarana dan prasarana; dan 5). Aspek manajemen pembiayaan mengacu pada standar pembiayaan.
\end{abstract}

Kata Kunci: Madrasah, Manajemen, Akreditasi

\section{A. Pendahuluan}

Madrasah memiliki latar belakang sejarahnya sendiri, walaupun sangat dimungkinkan ia merupakan konsekuensi dari pengaruh intensif pembaharuan pendidikan Islam di timur tengah masa modern. Pada paparan sejarah pendidikan Islam (khususnya madrasah) akan terlihat bahwa pendidikan Islam pada saat itu terkesan sebagai pendidikan yang tradisional dan jauh dari sentuhan-sentuhan kemajuan.
Oleh karena itu, kondisi tersebut secara alamiah akan membangun image masyarakat bahwa pendidikan Islam identik dengan pendidikan yang terbelakang yang hanya dikonsumsi oleh rakyat kecil. Anggapan terhadap kondisi pendidikan Islam ini, akan menimbulkan asumsi bahwa penyelenggaraan pendidikan Islam diselenggarakan dengan apa adanya. Selain itu asumsi-asumsi terhadap pendidikan ini juga di kuatkan oleh adanya kondisi pendidikan Islam yang 
kurang mendapat perhatian penuh dari pemerintah, sehingga pendidikan Islam termarginalkan dari pada pendidikan umum.

Seiring dengan perubahan sistem pendidikan di Indonesia dengan berlakunya Undang-undang Nomor 20 tahaun 2003 tentang Sistem Pendidikan Nasional (Sisdiknas), madrasah telah mendapatkan pengakuan yang kuat. Sisdiknas mengatur berkaitan jalur, jenjang dan jenis pendidikan. Jenis pendidikan mencakup pendidikan umum, kejuruan, akademik, profesi, vokasi, keagamaan, dan khusus (pasal 15). Dijelaskan pula bahwa pendidikan dasar berbentuk sekolah dasar (SD) dan madrasah ibtidaiyah (MI) atau bentuk lain yang sederajat serta sekolah menengah pertama (SMP) dan madrasah tsanawiyah (MTs), atau bentuk lain yang sederajat (pasal 17 (2)) dan Pendidikan menengah berbentuk sekolah menengah atas (SMA), madrasah aliyah (MA), sekolah menengah kejuruan (SMK), dan madrasah aliyah kejuruan (MAK), atau bentuk lain yang sederajat (pasal 18 (3). Rambu-rambu lainnya pemerintah juga telah menetapkan Peraturan Pemerintah Nomor 19 tahun 2005 tentang Standar Nasional Pendidikan yang telah dirubah menjadi menjadi Peraturan Pemerintah Nomor 32 tahun 2013 tentang perubahan Peraturan Pemerintah Nomor 19 tahun 2005 tentang Standar Nasional Pendidikan dijelaskan bahwa Standar Nasional Pendidikan adalah kriteria minimal tentang sistem pendidikan di seluruh wilayah hukum Negara Kesatuan Republik Indonesia. Lingkup Standar Nasional Pendidikan meliputi Standar Isi, Standar Proses, Standar Kompetensi Lulusan, Standar Pendidik dan Tenaga Kependidikan, Standar Sarana dan Prasarana, Standar Pengelolaan, Standar Pembiayaan, dan
Standar Penilaian Pendidikan. Untuk penjaminan dan pengendalian mutu pendidikan sesuai dengan Standar Nasional Pendidikan dilakukan evaluasi, akreditasi, dan sertifikasi (pasal 2).

Dengan demikian, madrasah wajib mematuhi dan memenuhi seluruh peraturan dan perundangan yang telah dijelaskan di atas. Salah bentuk kebijakan yang harus dilaksanakan bahwa madrasah harus di akreditasi sebagai bentuk penjaminan dan pengendalian mutu madrasah. Akreditasi adalah kegiatan penilaian kelayakan program dalam satuan pendidikan berdasarkan kriteria yang telah ditetapkan (UU Sisdiknas No 20 tahun 2003 pasal 1 ayat 22). Akreditasi sekolah/madrasah adalah proses penilaian secara komprehensif terhadap kelayakan satuan atau program pendidikan, yang hasilnya diwujudkan dalam bentuk sertifikat pengakuan dan peringkat kelayakan yang dikeluarkan oleh suatu lembaga yang mandiri dan profesional. ${ }^{1}$

Kegiatan akreditasi dilaksanakan madrasah tidak hanya sekedar formalitas dalam bentuk sertifikat, melainkan memiliki manfaat dan fungsi bagi madrasah. Manfaat akreditasi bagi madrasah adalah sebagai Acuan dalam upaya peningkatan mutu sekolah/madrasah dan rencana pengembangan sekolah/madrasah dan sebagai umpan balik dalam usaha pemberdayaan dan pengembangan kinerja warga sekolah/madrasah dalam rangka menerapkan visi, misi, tujuan, sasaran, strategi, dan program sekolah/madrasah. ${ }^{2}$ Sedangkan kegiatan akreditasi madrasah berfungsi untuk Pembinaan dan pengembangan, yaitu sebagai dasar bagi sekolah/madrasah,

\footnotetext{
1 Anonim, Pedoman Akreditasi, BAN S/M, 2014, hal. 5.

${ }^{2}$ Ibid, hal. 8
} 
pemerintah, dan masyarakat dalam upaya peningkatan atau pengembangan mutu sekolah/madrasah. ${ }^{3}$

Dengan demikian, akreditasi yang dilakukan oleh madrasah harus lebih bermanfaat bagi madrasah untuk bisa menjadi instrumen peningkatan dan pengembangan madrasah, sehingga madrasah tidak lagi dianggap sebagai satuan pendidikan yang diselenggarakan dengan apa adanya, namun sebagai satuan pendidikan yang dikelola dengan baik dan benar mengacu pada standar, sehingga madrasah mampu bersaing dengan jenis pendidikan lain pada setian jenjangnya.

Kondisi madrasah pada setiap jenjang yang ada didominasi oleh madrasah swasta termasuk di Kota Pekanbaru, Hal ini merupakan wujud dari bentuk partisipasi masyarakat muslim Kota Pekanbaru di bidang pendidikan, namun semangat ini belum diimbangi dengan kemampuan manajerial madrasah yang baik dan benar, sehingga mengakibatkan madrasah kurang mampu bersaing dengan dengan jenis pendidikan lain. Melihat kondisi tersebut, peneliti sangat tertarik untuk meneliti tentang Pemanfaatan Akreditasi dalam Peningkatan Manajemen Madrasah di Kota Pekanbaru (Studi Kasus di Madrasah Tsanawiyah Swasta Kecamatan Tampan Kota Pekanbaru)

\section{B. Kajian Teori}

1. Pengertian Akreditasi

Akreditasi sekolah/madrasah adalah proses penilaian secara komprehensif terhadap kelayakan satuan atau program pendidikan, yang hasilnya diwujudkan dalam bentuk sertifikat pengakuan dan peringkat

\footnotetext{
${ }^{3}$ Ibid, hal. 10
}

kelayakan yang dikeluarkan oleh suatu lembaga yang mandiri dan profesional. ${ }^{4}$

Penegasan tentang pentingnya akreditasi dapat dilihat pada Undangundang Nomor 20 Tahun 2003 tentang Sistem Pendidikan Nasional (Sisdiknas), Pasal 60, tentang Akreditasi yang berbunyi sebagai berikut: ${ }^{5}$

1). Akreditasi dilakukan untuk menentukan kelayakan program dan satuan pendidikan pada jalur pendidikan formal dan nonformal pada setiap jenjang dan jenis pendidikan.

2). Akreditasi terhadap program dan satuan pendidikan dilakukan oleh lembaga mandiri yang berwenang sebagai bentuk akuntabilitas publik.

3). Akreditasi dilakukan atas dasar kriteria yang bersifat terbuka.

Pelaksanaan akreditasi oleh BANS/M didasarkan atas Undang-undang Nomor 20 Tahun 2003 tentang Sistem Pendidikan Nasional khususnya pasal 60, serta Peraturan Pemerintah Nomor 19 Tahun 2005 tentang SNP. Dalam Peraturan Pemerintah Nomor 19 Tahun 2005, Pasal 86 dinyatakan hal-hal sebagai berikut. ${ }^{6}$

1).Pemerintah melakukan akreditasi pada setiap jenjang dan satuan pendidikan untuk menentukan kelayakan program dan/atau satuan pendidikan.

2). Kewenangan akreditasi sebagaimana dimaksud pada ayat (1) dapat pula dilakukan oleh lembaga mandiri yang diberi kewenangan oleh Pemerintah untuk melakukan akreditasi.

4 BAN-S/M, Kebijakan dan

Pedoman Akreditasi
Sekolah/Madrasah, http://www.bansm.or.id., 2009. h. 5

Afnil Guza, Sisdiknas, Op.Cit, pasal 60, h. 270.

${ }^{6}$ Afnil Guza, SNP Pasal 86, Op.Cit, h. 86 
3). Akreditasi sebagaimana dimaksud pada ayat (1) dan ayat (2) sebagai bentuk akuntabilitas publik dilakukan secara obyektif, adil, transparan, dan komprehensif dengan menggunakan instrumen dan kriteria yang mengacu kepada Standar Nasional Pendidikan.

Sebagai implementasi dari Peraturan Pemerintah Nomor 19 Tahun 2005 diterbitkan Peraturan Mendiknas Nomor 29 Tahun 2005. Peraturan Mendiknas tersebut menyatakan bahwa, BAN-S/M adalah badan evaluasi mandiri yang menetapkan kelayakan program dan/atau satuan pendidikan jenjang pendidikan dasar dan menengah jalur formal dengan mengacu pada SNP. ${ }^{7}$ Kemudian dinyatakan bahwa BAN-S/M merupakan badan nonstruktural yang bersifat nirlaba dan mandiri yang bertanggung jawab kepada Mendiknas. ${ }^{8}$ Sebagai institusi yang bersifat independen di bawah dan bertanggung jawab kepada Mendiknas, BAN-S/M adalah badan evaluasi mandiri yang menetapkan kelayakan program dan/atau satuan pendidikan jenjang pendidikan dasar dan menengah jalur formal dengan mengacu pada SNP. Selanjutnya, dinyatakan bahwa tugas BAN-S/M adalah merumuskan kebijakan operasional, melakukan sosialisasi kebijakan, dan melaksanakan akreditasi sekolah/madrasah. ${ }^{9}$ Dalam melaksanakan akreditasi sekolah/madrasah BAN-S/M dibantu oleh Badan Akreditasi Provinsi Sekolah/ Madrasah (BAP-S/M) ${ }^{10}$

2. Tujuan dan Manfaat Akreditasi Akreditasi sekolah/madrasah bertujuan untuk:

${ }^{7}$ Permendiknas No. 29 Tahun 2005 tentang $B A N-S / M$, Pasal 1(1).

${ }^{8}$ Ibid, Pasal 2 (2).

${ }^{9}$ Ibid, Pasal 7 (1).

${ }^{10}$ Ibid, Pasal 7 (5).
1).Memberikan informasi tentang kelayakan sekolah/madrasah atau program yang dilaksanakannya berdasarkan SNP;

2). Memberikan pengakuan peringkat kelayakan; dan

3). Memberikan rekomendasi tentang penjaminan mutu pendidikan kepada program dan/atau satuan pendidikan yang diakreditasi dan pihak terkait.

Hasil akreditasi

sekolah/madrasah bermanfaat sebagai:

1). Acuan dalam upaya peningkatan mutu sekolah/madrasah dan rencana pengembangan sekolah/madrasah;

2). umpan balik dalam usaha pemberdayaan dan pengembangan kinerja warga sekolah/madrasah dalam rangka menerapkan visi, misi, tujuan, sasaran, strategi, dan program sekolah/madrasah;

3). motivator agar sekolah/madrasah terus meningkatkan mutu pendidikan secara bertahap, terencana, dan kompetitif baik di tingkat kabupaten/kota, provinsi, nasional bahkan regional dan internasional;

4). bahan informasi bagi sekolah/madrasah sebagai masyarakat belajar untuk meningkatkan dukungan dari pemerintah, masyarakat, maupun sektor swasta dalam hal profesionalisme, moral, tenaga, dan dana; serta

5). acuan bagi lembaga terkait dalam mempertimbangkan kewenangan sekolah/ madrasah sebagai penyelenggara ujian nasional.

Manfaat bagi kepala sekolah/madrasah, hasil akreditasi diharapkan dapat dijadikan bahan informasi untuk pemetaan indikator kelayakan sekolah/madrasah, kinerja warga sekolah/madrasah, termasuk kinerja kepala sekolah/madrasah selama periode kepemimpinannya. Di samping itu, hasil akreditasi juga diperlukan 
kepala sekolah/ madrasah sebagai bahan masukan untuk penyusunan program serta anggaran pendapatan dan belanja sekolah/madrasah.

Manfaat bagi guru, hasil akreditasi merupakan dorongan untuk selalu meningkatkan diri dan bekerja keras dalam memberikan layanan terbaik bagi peserta didiknya guna mempertahankan dan meningkatkan mutu sekolah/madrasah. Secara moral, guru senang bekerja di sekolah/madrasah yang diakui sebagai sekolah/madrasah bermutu.

Manfaat bagi masyarakat dan khususnya orang tua peserta didik, hasil akreditasi diharapkan menjadi informasi yang akurat tentang layanan pendidikan yang ditawarkan oleh setiap sekolah/madrasah, sehingga secara sadar dan bertanggung jawab masyarakat dan khususnya orangtua dapat membuat keputusan dan pilihan yang tepat dalam kaitannya dengan pendidikan anaknya sesuai kebutuhan dan kemampuannya.

Manfaat bagi peserta didik, hasil akreditasi akan menumbuhkan rasa percaya diri bahwa mereka memperoleh pendidikan yang baik, dan harapannya, sertifikat dari sekolah/madrasah yang terakreditasi merupakan bukti bahwa mereka menerima pendidikan bermutu. $^{11}$

3. Fungsi Akreditasi Sekolah/Madrasah

Dengan menggunakan instrumen akreditasi yang komprehensif, hasil akreditasi diharapkan dapat memetakan secara utuh profil sekolah/madrasah. Proses akreditasi sekolah/madrasah berfungsi untuk hal-hal berikut. ${ }^{12}$

1) Pengetahuan, yaitu sebagai informasi bagi semua pihak tentang kelayakan sekolah/madrasah dilihat dari berbagai unsur terkait yang mengacu pada standar nasional pendidikan beserta indikator-indikatornya.

2) Akuntabilitas, yaitu sebagai bentuk pertanggungjawaban

sekolah/madrasah kepada publik, apakah layanan yang dilakukan dan diberikan oleh sekolah/ madrasah telah memenuhi harapan atau keinginan masyarakat.

3) Pembinaan dan pengembangan, yaitu sebagai dasar bagi sekolah/madrasah, pemerintah, dan masyarakat dalam upaya peningkatan atau pengembangan mutu sekolah/madrasah.

\section{Prinsip-prinsip Akreditasi Sekolah/} Madrasah

Prinsip-prinsip yang dijadikan pijakan dalam melaksanakan akreditasi sekolah/ madrasah adalah objektif, komprehensif, adil, transparan, akuntabel dan profesional. ${ }^{13}$

1) Objektif

Akreditasi sekolah/madrasah pada hakikatnya merupakan kegiatan penilaian tentang kelayakan penyelenggaraan pendidikan yang ditunjukkan oleh suatu sekolah/ madrasah. Dalam pelaksanaan penilaian ini berbagai aspek yang terkait dengan kelayakan itu diperiksa dengan jelas dan benar untuk memperoleh informasi tentang keberadaannya. Agar hasil penilaian itu dapat menggambarkan kondisi yang sebenarnya untuk dibandingkan dengan kondisi yang diharapkan maka dalam prosesnya digunakan indikator-indikator terkait dengan kriteria-kriteria yang ditetapkan.

2) Komprehensif

Dalam pelaksanaan akreditasi sekolah/madrasah, fokus penilaian tidak hanya terbatas pada aspek-aspek tertentu saja tetapi juga meliputi

\footnotetext{
${ }^{11}$ BAN-S/M, Op. Cit, h. 5

${ }^{12}$ Ibid, h. 7.
}

${ }^{13}$ Ibid. 
berbagai komponen pendidikan yang bersifat menyeluruh. Dengan demikian, hasil yang diperoleh dapat menggambarkan secara utuh kondisi kelayakan sekolah/madrasah tersebut.

3) Adil

Dalam melaksanakan akreditasi, semua sekolah/madrasah harus diperlakukan sama dengan tidak membedakan sekolah/madrasah atas dasar kultur, keyakinan, sosial budaya, dan tidak memandang status sekolah/madrasah baik negeri ataupun swasta. Sekolah/Madrasah harus dilayani sesuai dengan kriteria dan mekanisme kerja secara adil dan/atau tidak diskriminatif.

4) Transparan

Data dan informasi yang berkaitan dengan pelaksanaan akreditasi sekolah/madrasah seperti kriteria, mekanisme kerja, jadwal serta sistem penilaian akreditasi dan lainnya harus disampaikan secara terbuka dan dapat diakses oleh siapa saja yang memerlukannya.

5) Akuntabel

Pelaksanaan akreditasi sekolah/madrasah harus dapat dipertanggungjawabkan baik dari sisi penilaian maupun keputusannya sesuai dengan aturan dan prosedur yang telah ditetapkan.

6) Profesional

Pelaksanaan akreditasi sekolah/madrasah dilakukan oleh orang-orang yang memiliki kompetensi dan integritas yang tinggi.

5. Peningkatan

Manajemen

Madrasah Melalui Pemanfaatan Akreditasi

Pembaharuan pendidikan dilakukan terus menerus agar mampu menghadapi berbagai tantatangan sesuai perkembangan dengan zamannya. Dalam era reformasi dan demokratisasi pendidikan, tantangan yang dihadapi oleh sistem pendidikan meliputi persoalanpersoalan yang terkait dengan pemerataan, mutu, relevansi, dan efesiensi pendidikan.

Regulasi pendidikan di Indonesia menghasilkan beberapa peraturan dan perundang-undangan yang mengharuskan pemerintah membuat kebijakan-kebijakan berkaitan dengan pelaksanaan pendidikan di masyarakat baik itu lembaga yang didirikan negara maupun swasta. Kebijakan tersebut menyangkut semua lembaga pendidikan dari berbagai kementerian yang mendirikan sebuah lembaga pendidikan.

Undang-undang Nomor 20 tahun 2003 tentang Sistem Pendidikan Nasional pasal 60 ayat 1 dan 2 menegaskan bahwa akreditasi dilakukan untuk menentukan kelayakan program dan satuan pendidikan pada jalur formal dan nonformal pada setiap jenjang dan jenis pendidikan, serta akreditasi terhadap program dan satuan pendidikan dilakukan oleh pemerintah dan /atau lembaga mandiri yang berwenang sebagai bentuk akuntabilitas publik.

Penyelenggaraan akreditasi, sebagai salah satu kegiatan peningkatan mutu dibidang pendidikan, pada hakekatnya adalah suatu upaya agar penyelenggara pendidikan dapat mencapai standar kualitas yang ditetapkan dan pada gilirannya peserta didik dapat mencapai keberhasilan pendidikan, baik dalam penguasaan ilmu pengetahuan, keterampilan maupun pembentukan kepribadian.

Di samping itu perlu diupayakan penyelenggaraan akreditasi yang sesuai dengan paradigma baru dalam penyelenggara 
akreditasi, diantaranya adalah tidak lagi membedakan antara lembaga negeri dan swasta, mendayagunakan keterlibatan dan peran serta masyarakat, serta prinsip keterbukaan.

Madrasah sebagai bagian dari sistem pendidikan nasional dituntut untuk selalu berupaya meningkatkan kualitas dalam penyelenggaraan pendidikan, sehingga dapat menghasilkan lulusan yang berkualitas, mampu bersaing serta mampu menghadapi tantangan zaman. Penyelenggaraan pendidikan yang menghasilkan lulusan bermutu rendah sebenarnya merupakan pemborosan waktu, tenaga, dan biaya. Oleh karena itu, penyelenggara akreditasi madrasah, sebagai upaya pengendalian mutu dan peningkatan manajemen, baik melalui sistem penilaian hasil belajar, penerapan kurikulum, sarana, tenaga kependidikan, maupun melalui pengaturan sistem belajar mengajar adalah sebagai suatu keharusan.

Peningkatan manajemen madrasah harus mengacu pada instrumen dan kriteria akreditasi sekolah/madrasah dikembangkan berdasarkan standar yang mengacu pada Standar Nasional Pendidikan. Hal ini sesuai dengan Peraturan Pemerintah Nomor 19 Tahun 2005. ${ }^{19}$

Dengan menggunakan Standar Nasional Pendidikan sebagai acuan, setiap sekolah/madrasah diharapkan dapat mengembangkan pendidikannya secara optimal sesuai dengan karakteristik dan kekhasan programnya. Standar Nasional Pendidikan harus dijadikan acuan guna memetakan secara utuh profil kualitas sekolah/madrasah. Oleh karena itu, komponen instrumen

\footnotetext{
19 Ibid., Pasal 1 ayat (1)
}

akreditasi yang disusun didasarkan pada delapan Standar Nasional Pendidikan dan berdasarkan pada Permendiknas tentang penjabaran delapan Standar Nasional Pendidikan. Delapan komponen akreditasi sekolah/madrasah tersebut adalah:

1. Standar Isi

Standar isi adalah ruang lingkup materi dan tingkat kompetensi yang dituangkan dalam kriteria tentang kompetensi tamatan, kompetensi bahan kajian, kompetensi mata pelajaran, dan silabus pembelajaran yang harus dipenuhi oleh peserta didik pada jenjang dan jenis pendidikan tertentu. Penjelasan tentang Standar Isi ini dijelaskan melalui Permendiknas Nomor 22 Tahun 2006.

2. Standar Proses

Standar proses adalah Standar Nasional Pendidikan yang berkaitan dengan pelaksanaan pembelajaran pada satu satuan pendidikan untuk mencapai standar kompetensi lulusan. Penjelasan tentang Standar Proses dijelaskan melalui Permendiknas Nomor 41 Tahun 2007.

3. Standar Kompetensi Lulusan

Standar kompetensi lulusan adalah kualifikasi kemampuan lulusan yang mencakup sikap, pengetahuan, dan keterampilan. Penjelasan tentang Standar Kompetensi Lulusan dijelaskan melalui Permendiknas Nomor 23 Tahun 2006.

4. Standar Pendidik dan Tenaga Kependidikan

Standar pendidik dan tenaga kependidikan adalah kriteria pendidikan prajabatan dan kelayakan fisik maupun mental, serta pendidikan dalam jabatan. Penjelasan tentang Standar Pendidik dan Tenaga Kependidikan dijelaskan melalui Permendiknas Nomor 13 Tahun 2007 
tentang Kepala Sekolah, Permendiknas Nomor 16 Tahun 2007 tentang Guru, Permendiknas Nomor 24 Tahun 2008 tentang Tenaga Administrasi.

5. Standar Sarana dan Prasarana

Standar sarana dan prasarana adalah Standar Nasional Pendidikan yang berkaitan dengan kriteria minimal tentang ruang belajar, tempat berolahraga, tempat beribadah, perpustakaan, laboratorium, bengkel kerja, tempat bermain, tempat berkreasi dan berekreasi, serta sumber belajar lain, yang diperlukan untuk menunjang proses pembelajaran, termasuk penggunaan teknologi informasi dan komunikasi. Penjelasan tentang Standar Sarana dan Prasarana dijelaskan melalui Permendiknas Nomor 24 Tahun 2007.

6. Standar Pengelolaan

Standar pengelolaan adalah Standar Nasional Pendidikan yang berkaitan dengan perencanaan, pelaksanaan, dan pengawasan kegiatan pendidikan pada tingkat satuan pendidikan, kabupaten/kota, provinsi, atau nasional agar tercapai efisiensi dan efektivitas penyelenggaraan pendidikan. Penjelasan tentang Standar Pengelolaan dijelaskan melalui Permendiknas Nomor 19 Tahun 2007.

7. Standar Pembiayaan

Standar pembiayaan adalah standar yang mengatur komponen dan besarnya biaya operasi satuan pendidikan yang berlaku selama satu tahun. Penjelasan tentang Standar Pembiayaan dijelaskan melalui Peraturan Pemerintah Nomor 28 Tahun 2008.

8. Standar Penilaian Pendidikan

Standar penilaian pendidikan adalah Standar Nasional Pendidikan yang berkaitan dengan mekanisme, prosedur, dan instrumen penilaian hasil belajar peserta didik. Penjelasan tentang Standar Pengelolaan dijelaskan melalui Permendiknas Nomor 20 Tahun 2007.

Berdasarkan delapan standar nasional pendidikan maka dapat diklasifikasikan pada 5 aspek manajerial madrasah yaitu:

1. Aspek manajemen madrasah mengacu pada standar pengelolaan;

2. Aspek manaajemen kurikulum mengacu pada standar isi, standar proses, standar kompetensi lulusan, standar penilaian pendidikan;

3. Aspek manajemen sumber daya manusia mengacu pada standar pendidik dan tenaga kependidikan;

4. Aspek manajemen sarana dan prasarana mengacu pada standar sarana dan prasarana; dan

5. Aspek manajemen pembiayaan mengacu pada standar pembiayaan.

\section{Metode}

Penelitian ini menggunakan pendekatan ilmu manajemen terutama dari dua disiplin ilmu yaitu manajemen dan studi kebijakan pendidikan, yang fokus pada proses manajemen madrasah dengan memanfaatkan sistem akreditasi. Sehubungan dengan hal tersebut, maka penelitian ini bersifat deskriptif kualitatif.

Lokasi penelitian adalah madrasah di Kota Pekanbaru (khusus Madrasah Tsanawiyah Swasta Kecamatan Tampan), yaitu 1) Madrasah Tsanawiyah Al-Muttaqin yang beralamat dijalan H.R Soebrantas Desa Tuah Karya Kecamatan Tampan Pekanbaru, 2) Madrasah Tsanawiyah Darel Hikmah yang beralamatkm. $12 \mathrm{Jl}$. Manyar Sakti Simpang Baru PanamPekanbaru, 3) Madrasah Tsanawiyah Muhammadiyah 2 yang beralamat dijalan Srikandi, 4). Madrasah Tsanawiyah Al-Huda yang beralamat di jalan Soebrantas. 
Objek penelitian ini adalah pemanfaatan akreditasi dalam peningkatan manajemen madrasah. Sedangkan subjek penelitian ini adalah kepala madrasah serta semua yang terkait di wilayah cakupan penelitian.

Analisis data dalam penelitian meliputi reduksi data (data reduction), penyajian data (data display) serta Penarikan kesimpulan dan verifikasi (conclusion drawing / verification) sebagaimana diungkapkan Miles dan Hubermen dalam Sugiono. ${ }^{26}$

\section{Pembahasan}

Berdasarkan hasil wawancara yang telah dilakukan maka diperoleh informasi tentang Pemanfaatan Akreditasi dalam Peningkatan Manajemen Madrasah Di Kota Pekanbaru (Studi Kasus di Madrasah Tsanawiyah Swasta Kecamatan Tampan Kota Pekanbaru) untuk kepentingan 5 aspek manajemen madrasah sebagai berikut:

1. Aspek manajemen madrasah.

Madrasah memanfaatkan standar pengelolaan mengacu pada Permendiknas Nomor 19 Tahun 2007 sebagai dasar dalam mengelola madrasah.

Pemanfaatan pada aspek ini yang pertama dengan adanya proses penyusunan visi, misi dan tujuan madrasah dengan pelibatan stakeholders yang ada. Hal ini sejalan yang disampaikan oleh kepala madrasah tsanawiyah alMuttaqin:

"Visi dan Misi sekolah telah lama dibuat pada tahun 2003 oleh para pendahulu atau pendiri awal Mts. Al-Muttaqin dengan melibatkan
Kepala Sekolah beserta majlis Guru berjumlah delapan orang”.

Sebagaimana juga yang disampaikan oleh kepala madrasah tsanawiyah Muhammadiyah 2:

"Visi sekolah dibuat dengan melibatkan stekholder diantaranya komite sekolah, Majlis guru, dan masyarakat sekitar untuk bersama mendiskusikan dan membuat visi. Setiap guru diminta untuk membuat satu visi kemudian disatukan dan menghasilkan rumusan visi seperti saat ini yakni Berakhlakul karimah, cerdas berprestasi baik bidang akademik dan teknologi dan berwawasan lingkungan".

Senada juga sebagaimana yang disampaikan oleh kepala madrasah tsanawiyah al-Huda:

"terkait visi, misi dan tujuan sekolah proses perumusan saya formulasinya terlebih dahulu kirakira apa yang paling tepat sesuai dengan kondisi sekolah kita, kemudian saya bawak ke forum majlis guru, komite sekolah dan yayasan. Jadi dari formulasi yang saya tentukan saya tawarkan dan disana terjadi penyempurnaan tambahan ide-ide atau perbaikan sehingga disepakati dan dirumuskan visi, misi, tujuan sampai moto sekolah yang sesuai dengan kondisi sekolah yang ada".

Pemanfaatan kedua adanya penyusunan perencaan kerja baik jangka pendek, menengah maupun panjang sebagai perwujudan implementasi visi, misi dan tujuan madrasah dan Penyusunan program madrasah juga melibat pelibatan stakeholders yang ada.

${ }^{26}$ Sugiyono. Metodologi Penelitian Kualitatif. Bandung: Alfabeta, 2008, hal. 72 
Berkaitan dengan hal ini dijelaskan oleh kepala madrasah tsanawiyah Darel Hikmah:

"Untuk merealisasikan visi tadi maka madrasah menyusun perencanaan dengan program kerja, ada program harian, mingguan, bulanan dan tahunan. Untuk disekolah ini kepala sekolah dibantu oleh empat wakil, yakni bidang kurikulum, kesiswaan, sarana dan prasarana serta humas. Jadi masing-masing ini membuat program kerja tentunya berdasarkan visi misi di atas".

Hal ini juga sejalan sebagaimana yang di jelaskan oleh kepala madrasah tsanawiyah al-Huda:

"Untuk mewujudkan itu semua maka saya membuat program kerja baik kerja jangka pendek, jengka menengah, dan jangka panjang. Termasuk disana disebutkan indikator-indikator pencapaian, semua itu kami wujudkan sebagai program kepala sekolah yang diketahui yayasan dan pengawas sekolah sehingga dalam perjalanannya kita dapat pantau dan evaluasi sehingga dapat dilihat program yang perlu dipertahankan, atau ditinggalkan, diprioritaskan yang cocok sesuai dengan kondisi sekolah. Biasanya di sekolah swasta berada di Yayasan menjadi penialaian yayasan kepada kita sehingga penialaiannya dari program-program yang dilakukan sejauh mana kita memaksimalkan kondisi apa yang ada".

Pemanfaatan yang ketiga untuk penyusunan sistem atau panduan kerja yang ada pada setiap unit sehingga memungkinkan adanya konsistensi kegiatan dalam mencapai tujuan.
Hal ini tergambar dari adanya proses penyusunan visi, misi dan tujuan madrasah dengan pelibatan stakeholders yang ada. Adanya aktifitas penyusunan perencaan kerja baik jangka pendek, menengah maupun panjang sebagai perwujudan implementasi visi, misi dan tujuan madrasah. Penyusunan program madrasah juga melibat pelibatan stakeholders yang ada. Adanya aktifitas penyusunan sistem atau panduan kerja yang ada pada setiap unit sehingga memungkinkan adanya konsistensi kegiatan dalam mencapai tujuan.

2. Aspek manajemen kurikulum Madrasah menjadikan standar isi Permendiknas Nomor 22 Tahun 2006, standar proses Permendiknas Nomor 41 Tahun 2007, standar kompetensi lulusan Permendiknas Nomor 23 Tahun 2006, standar penilaian pendidikan Permendiknas Nomor 20 Tahun 2007 sebagai dasar dalam manajemen kurikulum. Hal ini tergambar dari adanya aktifitas penyusunan kurikulum yang melibatkan stakholders yang ada dan tersedianya dokumen kurikulum madrasah. Implementasi kurikulum madrasah memiliki kesulitan tersendiri hal ini dikarenakan madrasah harus mengimplementasikan KTSP pada mata pelajaran umum dan kurikulum 2013. Dalam hal proses pembelajaran tentunya disesuaikan kurikulum yang dipakai dan fasilitas yang tersedia. Aktifitas madrasah dalam mempersiapkan UN melalui berbagai kegiatan diantanya dengan memberikan terobosan menjelang UN, khusus MTs Muhammadiyah 2 tidak memberikan terobosan tetapi melalui penambahan 2 jam pelajaran untuk mata pelajaran yang diUNkan selama di kelas IX dan untuk MTs Al-Huda memberikan penambahan 1 
jam pelajaran untuk mata pelajaran yang diUNkan selama di kelas IX dan tetap memberikan terobosan.

3. Aspek manajemen sumber daya manusia

Madrasah menjadikan standar pendidik dan tenaga kependidikan sebagai pedoman manajemen sumber daya manusia pendidikan. Hal ini tergambar dari mayoritas guru yang ada telah memenuhi kualifikasi dan konpetensi yang dipersyaratkan dan telah $65 \%$ guru telah tersertifikasi. Namun untuk tenaga kependidikan belum memenuhi standar kualifikasi dan kompetensi yang dibutuhkan sehingga aspek pengelolaan kearsipan madrasah menjadi hal yang sangat bermasalah. Pembinaan sumber daya manusia pendidikan dilakukan melalui pemberian kesempatan untuk melanjutkan studi dan peningkatan kompetensi dengan diikutsertaan dalam kegiatan seminar/lokakarya baik yang dilaksanakan sendiri maupun oleh instansi luar serta setiap guru wajib aktif di MGMP.

4. Aspek manajemen sarana dan prasarana

Madrasah mengacu pada standar sarana dan prasarana sebagaimana dijelaskan pada Permendiknas Nomor 24 Tahun 2007 dalam manajemen madrasah. Hal ini terlihat dengan telah dilengkapinya semua standar sarana dan prasarana yang dipersyaratkan sehingga proses pembelajaran dapat berjalan dengan lancar, namun demikian rata-rata masih dalam sebatas ada dan tingkat representatif (pemenuhan standar) dan kenyamanan belum memadai. Khusus untuk MTs Muhammadiyah telah memenuhi standar dan kenyamanan. Kesulitan madrasah dalam pemenuhan standar ini adalah faktor swasta, keterbatasan pendanaan, keterbatasan lahan.

5. Aspek manajemen pembiayaan Madrasah mengacu pada standar pembiayaan dalam manajemen pembiayaan. Hal ini tergambar dengan adanya kegiatan penyusunan anggaran madrasah yang melibatkan stakholder yang ada, sehingga seluruh program yang ada dapat terealisasi. Sumber pembiayaan rata-rata bersumber dari SPP dan BOS/M serta sumber lainnya. Kendala pengelolaan keuangan adalah sistem pengelolaan keuangan dilakukan satu pintu di yayasan.

\section{E. Kesimpulan}

Berdasarkan analisis data penelitian yang telah dilakukan maka diperoleh informasi tentang Pemanfaatan Akreditasi dalam Peningkatan Manajemen Madrasah Di Kota Pekanbaru (Studi Kasus di Madrasah Tsanawiyah Swasta Kecamatan Tampan Kota Pekanbaru) untuk kepentingan 5 aspek yaitu: 1). Aspek manajemen madrasah mengacu pada standar pengelolaan; 2). Aspek manajemen kurikulum mengacu pada standar isi, standar proses, standar kompetensi lulusan, standar penilaian pendidikan; 3). Aspek manajemen sumber daya manusia mengacu pada standar pendidik dan tenaga kependidikan; 4). Aspek manajemen sarana dan prasarana mengacu pada standar sarana dan prasarana; dan 5).Aspek manajemen pembiayaan mengacu pada standar pembiayaan.

Pemanfaatan aspek di atas dilakukan oleh madrasah sebagai bentuk pemenuhan standar mutu 
madrasah sebagaimana yang telah ditetapkan oleh peraturan perundang-undangan dan kepentingan persiapan akreditasi madrasah secara berkelanjutan.

\section{F. Daftar Pustaka}

Anonim, Pedoman Akreditasi, BAN S/M, 2014

BAN-S/M, Kebijakan dan Pedoman Akreditasi Sekolah/Madrasah, http://www.ban-sm.or.id., 2009.

Creswell, J. W. Qualitative inquiry and research design : choosing among five tradition. London : Sage Publication. 1998

Lexy Moleong, Metode Penelitian Kualitatif. Bandung : Remaja Rosdakarya, 2007.

Nur Indriantoro, dan Bambang Supomo. Metodologi Penelitian Bisnis Untuk Akuntansi \& Manajemen. Yogyakarta: BPFE-Yogyakarta. 1999

Permendiknas No. 29 Tahun 2005 tentang $B A N-S / M$

Peraturan Mendiknas Nomor 29 Tahun 2005 Tentang Badan Akreditasi Nasional Sekolah/Madrasah

Peraturan Pemerintah Nomor 19 Tahun 2005 tentang Standar Nasional Pendidikan,

Sugiyono. Metodologi Penelitian Kualitatif. Bandung: Alfabeta, 2008 